Article

\title{
The Role of Managerial Cognitive Capability in Developing a Sustainable Innovation Ecosystem: A Case Study of Xiaomi
}

\author{
Xin Cao ${ }^{1}{ }^{1}$, Taohua Ouyang ${ }^{1}$, Puzant Balozian ${ }^{2}{ }^{\mathbb{D}}$ and Sixuan Zhang ${ }^{1, *}$ \\ 1 School of Economics and Management, Beihang University, Beijing 100191, China; \\ caoxin22@buaa.edu.cn (X.C.); taohuaouyang@buaa.edu.cn (T.O.) \\ 2 Adnan Kassar School of Business, Lebanese American University, Beirut 1102, Lebanon; \\ puzant.balozian@lau.edu.lb \\ * Correspondence: sixuan_zhang@buaa.edu.cn
}

Received: 17 July 2020; Accepted: 31 August 2020; Published: 2 September 2020

\begin{abstract}
Establishing a hub-based innovation ecosystem is an effective way for companies to cope with technological transformation and achieve sustainable development. While existing literature has explored how a hub firm develops or manages an innovation ecosystem, little attention has been paid to the strategic challenges in the development and management process. In strategic management, managerial cognitive capability has been proposed as a key factor that influences how firms make strategic changes and adapt to dynamic environments. Hence, from the perspective of managerial cognitive capability, this paper strives to investigate the development of an innovation ecosystem from the perspective of managerial cognitive capability. To do so, we conducted a qualitative case study of Xiaomi's innovation ecosystem from 2010 to 2019. The research adopts an interpretive approach and finds that (1) the evolution of the innovation ecosystem can be divided into incubation, growth, and regeneration periods, with developing core products, related products, and unrelated products as respective focus; (2) under rapid technological and market changes, it is critical to match the managerial cognitive capability of the hub-firm with its innovation ecosystem; (3) building innovation ecosystems enables the hub-firm to achieve sustainable competitive advantages. The study builds a model for the growth of innovation ecosystems and enriches theoretical research on innovation ecosystems and managerial cognitive capability.
\end{abstract}

Keywords: innovation ecosystems; managerial cognitive capability; case study; Xiaomi; strategic transformation

\section{Introduction}

The rapid changes in digital technologies and global markets motivate incumbent firms to continuously develop innovations that take advantage of advanced technologies and meet the various demands of customers [1]. Such continuous efforts drive incumbent firms to engage in developing innovation ecosystems (e.g., Apple's IOS ecosystem, Google's Android ecosystem, etc.) [2,3]. An innovation ecosystem can be described as a loosely interconnected network of firms and other entities that work collaboratively and competitively to deliver new products and services [4]. It is characterized by common goals, shared knowledge and skills, and established interdependence among its members [5,6].

In this study, we aim to examine a specific type of innovation ecosystems, that is, a hub-based innovation ecosystem. A hub-based innovation ecosystem assumes a single firm the ecosystem leader which sets the common goals, orchestrates the resource of the ecosystem, and exerts influence over the 
businesses of other members [7]. Existing research related to a hub-based innovation ecosystem has focused primarily on how a hub firm develops or manages an innovation ecosystem [8,9]. This research shows that such innovation ecosystems enable hub firms to rapidly develop new products and serves to meet the changing market demand and maintain sustainable development [10,11]. However, developing and managing such ecosystems also pose challenges to hub firms as they have to constantly reorient their strategic directions and adapt to the dynamic environments [12].

In strategic management, managerial cognitive capability has been proposed as a key factor that influences how firms make strategic changes and adapt to dynamic environments [13,14]. Managerial cognitive capability refers to the capacity of top managers to engage in different mental activities that comprise cognition [15]. It is a foundation of dynamic managerial capability which might pose a potential impact on strategic changes of firms [15]. Hence, in a hub-based innovation ecosystem, the managerial cognitive capability of the hub firm might influence how the firm develops and manages the innovation ecosystem as the development and management process include various strategic changes in a dynamic environment [16].

This research strives to investigate the development of an innovation ecosystem from the perspective of managerial cognitive capability. To do so, we conducted a longitudinal case study of Xiaomi, a leading Chinese Internet company and also a fortune 500 company. Starting as a smartphone company in 2010, Xiaomi has since then engaged in building an innovation ecosystem including a variety of innovations including smartphone-related products such as power banks and headphones, smart devices such as electric bulbs, and floor-sweeping robot, and daily consumables such as toothbrush and towels. In developing its innovation ecosystem, the top management of Xiaomi has demonstrated strong managerial cognitive capability in making strategic changes and adapting to the dynamic market. Hence, Xiaomi's innovation ecosystem provides us a rich research context to explore the role of managerial cognitive capabilities in influencing the development of a hub-based innovation ecosystem.

This study makes contributions to the fields of innovation ecosystems, managerial cognitive capabilities, and strategic management. First, regarding studies on innovation ecosystems, our study answers the call for the exploration of the role of different managerial cognitive capabilities in developing innovation ecosystems [17]. Additionally, while extant research emphasizes the importance of management in developing an innovation ecosystem $[8,10,18]$, this study extends this view by showing that the evolution of innovation ecosystems drives the development of management. Second, regarding studies on managerial capabilities and strategic management, the driving effects of managerial cognitive capabilities on the development of Xiaomi's innovation ecosystem confirms with previous literature that managerial cognitive capabilities function as a micro foundation that facilitates strategic changes $[14,19,20]$. Moreover, our findings contribute to related strategic management research $[15,21$, 22] by showing the mutual influence between managerial cognitive capability and strategic changes. Further, while most studies on managerial cognitive capabilities focus on individual entrepreneurs [15], this study makes contributes by focusing on management at a group level.

The rest of this paper is organized as follows: Section 2 first reviews the literature on innovation ecosystems, we then introduce the theoretical lens of managerial cognitive capability. In particular, we highlight the importance of studying the development of the innovation ecosystem from the perspective of managerial cognitive capabilities Section 3 outlines our research methodology, including case description, data collection, and analysis processes. Section 4 introduces the case of Xiaomi. Specifically, we describe the evolution of the innovation ecosystems along with the development of managerial cognitive capabilities, as well as their mutual influences. Section 5 elaborates on the development path of the innovation ecosystem of Xiaomi, analyzes the mechanism of interaction between managerial cognitive capability and the evolution of its innovation ecosystem, and discusses the cross-level mechanism and factors influencing managerial cognitive capability; Section 6 summarizes the findings of the study, the implications drawn from the findings, the corresponding contributions to the fields of innovation ecosystems, managerial cognitive capabilities, as well as the limitations of the research. 


\section{Theoretical Background}

\subsection{Innovation Ecosystems}

The birth of the term "business ecosystem" was motivated by the collaboration and competition among firms from different industries which are analogous to the biological ecosystem [23]. When Moore [4] first proposed the concept of "business ecosystem", he defined it as an economic association based on the interaction among different organizations that perform different functions, share resources, and jointly promote the development of the system. Given the dynamic business environment, Moore [19] further proposed a basic framework for the stages of the business ecosystem, which includes exploration, expansion, authority, and update (or death). The business ecosystem facilitates interdependency and dynamic co-evolution [20]. In the context of the Internet of things, Rong et al. [24] extend the concept of the business ecosystem by proposing the 6C framework which includes context, construct, configuration, cooperation, capability, and change. Taking a geographic perspective, Shi and Shi [25] further understand the business ecosystem as a schema for regional ecosystems. Specifically, the value creation process in the business ecosystem transforms embedded local resources to value networks which further create a feedback loop that brings new resources and opportunities to local resource pools.

Subsequently, the basic concept of the business ecosystem has been applied to the innovation management field. Specifically, the concept of a business ecosystem has been widely adopted by academics in the field of innovation to study the interrelated innovation networks and ecosystems [26-29]. For example, Adner [30] considered the business ecosystem an innovation ecosystem, he proposed that "the collaborative arrangements through which firms combine their offerings into a coherent, customer-facing solution". Zahra and Nambisan [31] defined the innovation ecosystem as a group of companies that interacts and shares a set of dependencies as it produces the goods, technologies, and services customers need.

The term innovation ecosystem has been adopted in various fields and referred to as different contexts [2]. For example, it has been described as the context of open innovation [32], the strategic context upon which a firm's performance relies [33], an institutional context where firms collaboratively develop innovations [34], a complex adaptive context where various actors interact with each other and evolve together [35], and an industrial context that highlights the transformative nature of the system [36]. Additionally, the term has recently been conceptualized as the platform based-ecosystem or digital ecosystem, the regional ecosystem, and the industrial ecosystem [2]. It has been adapted to various studies as illustrated below. For example, Zhang and Liang [37] defined an innovation ecosystem as composed of three circles, namely "core business", "network expansion" and "ecosystem". Huang et al. [38] studied that the market orientation, interaction orientation, and entrepreneurial orientation generate a positively reinforcing effect on the paths of the innovation ecosystem model in all phases. Gan et al. [3] found that the development of the innovation ecosystem has gone through the formation period, the incubation period, and the development period, and is affected by extrapolation drive, hybrid drive, and internal drive. Ding and $\mathrm{Wu}$ [39] revealed that the cultivation path of the vehicle innovation ecosystem can be divided into products and complementary products innovation, scale and rapid growth of the industry, and the formation of an innovation ecosystem. And deduced the symbiotic process model among communities, and the substitutive process model between CNG vehicle and other vehicle innovation ecosystems. Innovation ecosystem sustainable development relies on two major dual forces: the exploitative function and the generative or autopoiesis function [2]. Previous studies have shown that a firm's ability to successfully commercialize a new product depends not only on its technology strategy but also its capabilities to manage an innovation ecosystem strategy [40]. Since the construction and evolution of an enterprise innovation ecosystem usually involves one or more core companies acting as leaders and facilitators, the role of core companies is particularly important in situations of high uncertainty and ambiguity [41]. Focal firms in the innovation ecosystem resolve innovation paradoxes with structural, contextual, and coordinated 
ambidextrous capabilities, and build innovation paradox management mechanisms by establishing dual sustainable strategic innovation units, strengthening sustainable organizational ties between the internal and external, while co-creating and sharing innovation values, and, finally, promoting the formation and development of their sustainable innovation ecosystem [12]. Jiang et al. [9] argued that the core firm constructs an innovation platform, connects, interacts, and collaborates with different organizations and individuals at different levels. The coordination of the innovation ecosystem ensures value appropriability and reduces conflicts between partners.

While these studies shed light on the management and development of innovation ecosystems, they pay little attention to the role of managers in these processes. We argue that it is important to examine the how managerial cognitive capability influence the development and management of innovation ecosystems as managerial cognitive capability not only plays important role in the firm's innovation process but also affect the firms' strategic transformation that is highly related to how a firm develop an innovation ecosystem [11,12,39]. Next, we discuss the concept of managerial cognitive capability.

\subsection{Managerial Cognitive Capability}

Managerial cognitive capability is defined as "the capacity of an individual manager to perform one or more of the mental activities that comprise cognition" [15]. Managerial cognitive capability affects the development of innovations [42]. Three types of managerial cognitive capability are proposed: perception, problem-solving and reasoning, language, and communication. Perception refers to the mental activities of organizing and interpreting information from the external environment [43]. Problem-solving and reasoning describe the process of finding a way to deal with a specific problem and achieved the desired goal [44]. Language and communication are defined as a way of representing and delivering ideas.

Since it was proposed in 2015 , the term managerial cognitive capability has been widely adopted in various studies. For example, Teece et al. [45] applied the concept to study dynamic capabilities and organizational agility. Felin et al. [46] understood managerial cognitive capability as the micro foundation of the organizational strategies. Helfat and Martin [47] developed the term under the context of dynamic managerial capabilities. Maitland and Sammartino [48] study the role of managerial cognitive capabilities in influencing internationalization. In a changing environment, managers can make either positive or negative contributions based on their cognitive capability [13]. Research indicates that managerial cognitive capability functions as the micro foundation of the dynamic managerial capability, which further influence the corporate strategic transformation and performance [15]. Strategic transformation highlights "differences from the past", including the changes of a firm's direction [49]. Strategic transformation involves the continuous improvement and upgrading made by companies [50]. Such improvement and upgrading influence the long-term development of the company, help the company to effectively respond to the changing environment, and achieve sustainable development.

Managerial cognitive capability affects strategic transformation, manifested by the influences of perceiving opportunities on identifying and creating markets, solving problems, making a strategic investment, adjusting business model, and restructuring resources [15,51]. For example, Eggers and Kaplan [52] indicated that CEOs who pay more attention to emerging technologies enter new markets more rapidly. Tyler and Gnyawali [53] argued that the cognition structures of managers influence their decisions and the development of new products. Danneels [54] showed that managers' misevaluation of resources leads to the death of companies.

The development of an innovation ecosystem involves numerous strategic transformations. Hence, in the context of our study. We assume that managerial cognitive capability plays a crucial role in the evolution of the innovation ecosystem. The purpose of the research, is, therefore, to explore such a role. Having now described our theoretical, next we depict our research method. 


\section{Research Method}

This research adopts an exploratory single-case methodology. The research aims to explore how a hub firm develops an innovation ecosystem from the perspective of managerial cognitive capability, an area that has not been systematically studied in previous literature. According to Yin [55], case studies are suitable for explorative research such as ours. This research aims to answer the question of how managerial cognitive capability affects the development process of the innovation ecosystem. It aims to answer a "how" research question and to present a dynamic evolutionary process. Hence, it is suitable to use case study methods. Related literature also used the exploratory single-case study to study the innovation ecosystem, and reached some valuable conclusions [9,12]. Additionally, an in-depth investigation of a single case provides us a rich research context to dive into the deep analysis of the mechanisms that explain the role of managerial cognitive capability in the evolution of a hub firm's innovation ecosystem [55].

Further, an interpretive approach is adopted as no previous theory can explain the researched phenomenon of this study [56]. The established knowledge of managerial cognitive capability is utilized to guide our research design and data collection process at the beginning, enabling us to collect data based on existing knowledge [57]. Moreover, the iterative process of data collection and analysis allows us to identify new knowledge from the rich data collected from the research site, mitigating the bias of strict adherence to prior knowledge [58].

\subsection{Research Site}

We choose Xiaomi as our research site. The choice follows the principles of importance and representation. As a leading Internet company in China, Xiaomi is qualified to represent other companies with the same characteristics in terms of its strategies in developing an innovation ecosystem. So far, Xiaomi is the world's largest smart devices seller and the biggest smart device platform. Additionally, the choice follows the principles of theoretical sampling [59]. The choice of the research site should base on the need to fill theoretical gaps and develop new theories. Previous literature pays little attention to the mechanisms that explain the evolution of innovation ecosystems from the perspective of managerial cognitive capability. Based on the case of Xiaomi's innovation ecosystem, this research aims to open the "black box" of how a hub firm develops an innovation ecosystem with managerial cognitive capability, which will help advance research in both the fields of managerial cognitive capability and innovation ecosystems. Finally, the choice conforms to the principle of matching theoretical goals with case objects [60]. The authors were impressed by the important roles of managerial cognitive capability in the development of Xiaomi's innovation ecosystem and also had complete access to the related data.

\subsection{Data Collection and Analysis}

Our data collection and analysis process occurred simultaneously through three phases [61]. In the first phase, we collected and read related documents (e.g., online articles and videos, internal files) to identify problems of the research. Our review of related literature also shows that while extant literature has examined how a hub firm develops or manages an innovation ecosystem, how the hub firm deals with the strategic challenges in the development and management process is largely unexplored. In strategic management literature, the managerial cognitive capability has been proposed as a key factor that influences how firms make strategic changes and adapt to dynamic environment Hence, this research aims to discover the interrelation and interdependence between managerial cognitive capability and the development of innovation ecosystems.

In the second phase, we engaged in the case study design and data collection process. Interview and conservation were our primary ways to collect data. Specifically, we started the field study in Xiaomi in April 2017 and followed the important events and changes in the company's innovation ecosystem. In terms of data collection, we adopted a pyramid design and selected multi-level key information providers (including top managers, department managers, and junior employees). 
Interviews and discussions covered various aspects, such as Xiaomi's development strategy and management, managers' characteristics, corporate culture, product development, and innovation ecosystem development. Due to the exploratory nature of this research and its purpose to build theories, we allow the interviewees to describe the facts and explain their insights, which helps expand existing knowledge and discover new insights. We conducted two rounds of interviews, in the first round, we asked our respondents to describe the development of Xiaomi's innovation ecosystem. This round of interviews helps us to propose our research questions and develop a plan for the next round. The second round of interviews included semi-structured interviews with department managers and Xiaomi's Fans, which provided us with detailed information on the managerial cognitive capabilities of managers and the development of the innovation ecosystem. We interviewed middle-senior managers and technical leaders from six departments as they were important informants, we believed would provide us important information related to our research phenomenon (see Table 1). In total, a record of up to 168,119 Chinese characters was produced covering key questions, such as "What did the entrepreneurs and senior leadership teams do in the different development phases of the innovation ecosystem?" "What are the features of technology and businesses in the era of IoT?" and "What adjustments have been made in developing the innovation ecosystem?" We also attended the launch conference of Xiaomi phones in April 2017, and the AIoT Xiaomi Developer Conference in November 2018. We collected secondary data employing the Internet and online publications. We also collected a variety of secondary data to complement our primary data, to improve the reliability of research results [62]. For example, documents and archives, including Xiaomi's internal books "Participants" and "Mi Ecological Chain Battlefield Notes", meeting notes, media interviews, published articles and WeChat official accounts were utilized as secondary sources for analysis.

In the third phase, we dived in our data analysis process. We followed the coding techniques proposed by Strauss and Corbin [63]. Based on literature review and data collection, the data were analyzed by the following procedures: first, mentions related to the development of Xiaomi's innovation ecosystem and different types of managerial cognitive capability were extracted (open coding). Second, we grouped mentioned related to the innovation ecosystem by different phases and aggregate codes of managerial cognitive capability with conceptual similarities under the same theme (axial coding). Third, we linked the different types of managerial cognitive capability with the development of the innovation ecosystem (selective coding). Theoretical saturation was reached as no new insights can be drawn from our data [64].

Various techniques were adopted to ensure reliability and validity (see Figure 1) [59]. In the process of data collection and analysis, we applied the data triangulation approach, and also cross-checked our findings with employees from Xiaomiso as to obtain reliability and validity in this case study.

Figure 1 summarizes our research methods. Specifically, from January to March 2017, initial interview data were studied, and the chronological timeline of Xiaomi was formed. After analyzing the initial interview and reviewed relevant studies, we chose managerial cognitive capability as our theoretical concept that guided our further data collection and analysis. From April to June 2017, we engaged in onsite visits. We interviewed relevant respondents in Xiaomi and readjusted the framework as we analyzed newly collected data. Follow-up interviews were conducted from July to August 2017 when we realized that the interview data were not enough to support the theoretical analysis. Those interviews were collected via phone calls and emails to assure data-theory-model alignment. 
Table 1. Interviewee information and interview focus.

\begin{tabular}{|c|c|c|c|c|}
\hline Type & Position & Content & Length & Word Number \\
\hline \multirow{5}{*}{ Interviews } & Vice President & $\begin{array}{l}\text { Reasons for founding Xiaomi, } \\
\text { introduction to senior teams, } \\
\text { strategic evolution }\end{array}$ & $60 \mathrm{~min}$ & 8735 \\
\hline & $\begin{array}{c}\text { Manager, Public Affairs } \\
\text { Department }\end{array}$ & $\begin{array}{l}\text { Development course of Xiaomi } \\
\text { and its products }\end{array}$ & $40 \mathrm{~min}$ & 12,538 \\
\hline & Marketing Director & $\begin{array}{l}\text { Introduction to open platforms } \\
\text { and internal product } \\
\text { test mechanism }\end{array}$ & $40 \mathrm{~min}$ & 13,286 \\
\hline & Manager, Activity Operation & $\begin{array}{l}\text { Offline product-level activities } \\
\text { and community user maintenance }\end{array}$ & $60 \mathrm{~min}$ & 13,240 \\
\hline & Manager, Brand Operation & Marketing and branding activities & $60 \mathrm{~min}$ & 15,357 \\
\hline $\begin{array}{l}\text { Phone } \\
\text { Launch }\end{array}$ & Founder, Chairman and CEO & Launch of Xiaomi Mi 6 & $100 \mathrm{~min}$ & 17,824 \\
\hline \multirow{4}{*}{$\begin{array}{l}2018 \text { AIoT Xiaomi } \\
\text { Developer } \\
\text { Conference }\end{array}$} & Founder, Chairman and CEO & $\begin{array}{l}\text { Introduction to Xiaomi's core } \\
\text { strategy AI+IoT }\end{array}$ & $40 \mathrm{~min}$ & 9806 \\
\hline & $\begin{array}{l}\text { General Managers of } \\
\text { IoT Department }\end{array}$ & $\begin{array}{c}\text { Introduction to Xiaomi's AIoT and } \\
\text { its application } \\
\text { in different scenarios }\end{array}$ & $30 \mathrm{~min}$ & 7571 \\
\hline & President, IKEA China & $\begin{array}{l}\text { Strategic cooperation between } \\
\text { IKEA and Xiaomi }\end{array}$ & $15 \mathrm{~min}$ & 7035 \\
\hline & $\begin{array}{l}\text { Founder, Chairman, } \\
\text { and } \mathrm{CEO} \text {, Automotive }\end{array}$ & $\begin{array}{l}\text { Cooperation between Leading } \\
\text { Ideal Automotive and Mi AI } \\
\text { Speaker for comprehensive } \\
\text { Internet services }\end{array}$ & $25 \mathrm{~min}$ & 4980 \\
\hline Return Visit & $\begin{array}{l}\text { Members, Xiaomi New } \\
\text { Economy Research Center }\end{array}$ & $\begin{array}{l}\text { Discussion about Xiaomi's } \\
\text { positioning and future } \\
\text { development direction } \\
\text { after its IPO }\end{array}$ & $40 \mathrm{~min}$ & 26,427 \\
\hline
\end{tabular}




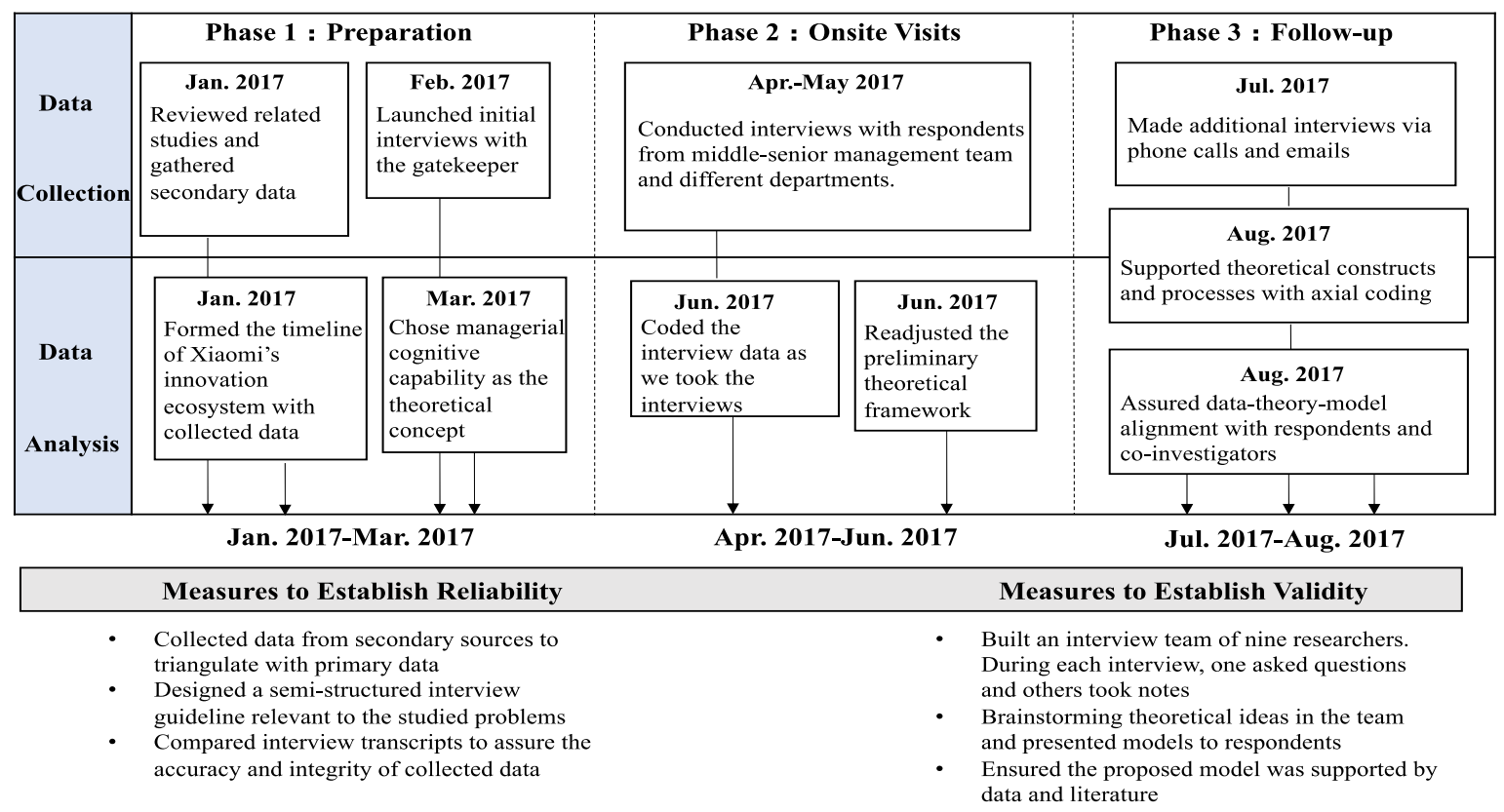

Figure 1. Overview of research methods.

\section{Case Description}

Founded in 2010, Xiaomi Inc. is an innovative technology corporation dedicated to developing smartphones and establishing an innovation ecosystem. Mi phones are Xiaomi's core products. Additionally, MIUI, MiTalk, Mi Box, Mi TV, and Mi Router are its private brands. Further, a variety of other products falls into more than 2700 segments in 15 areas of the innovation ecosystem, including intelligence, furniture, and grocery. In March 2018, Xiaomi became the world's fourth-largest smartphone manufacturer with an accumulative production volume of more than 260 million. In addition to its core product, the smartphone, Xiaomi incubated 270 companies (see Appendix A Table A1). With 132 million devices connected to its smart device network and more than 400 partners, Xiaomi has become the world's largest smart device platform. On 9 July 2018, Xiaomi went public in Hong Kong. In July 2019, Xiaomi entered the Fortune 500 and became the youngest Fortune 500 company. Since its establishment, Xiaomi has experienced three developmental stages: Incubation, growth, and regeneration stage (see Figure 2). Each stage has different characteristics and the analyses of them are as follows.

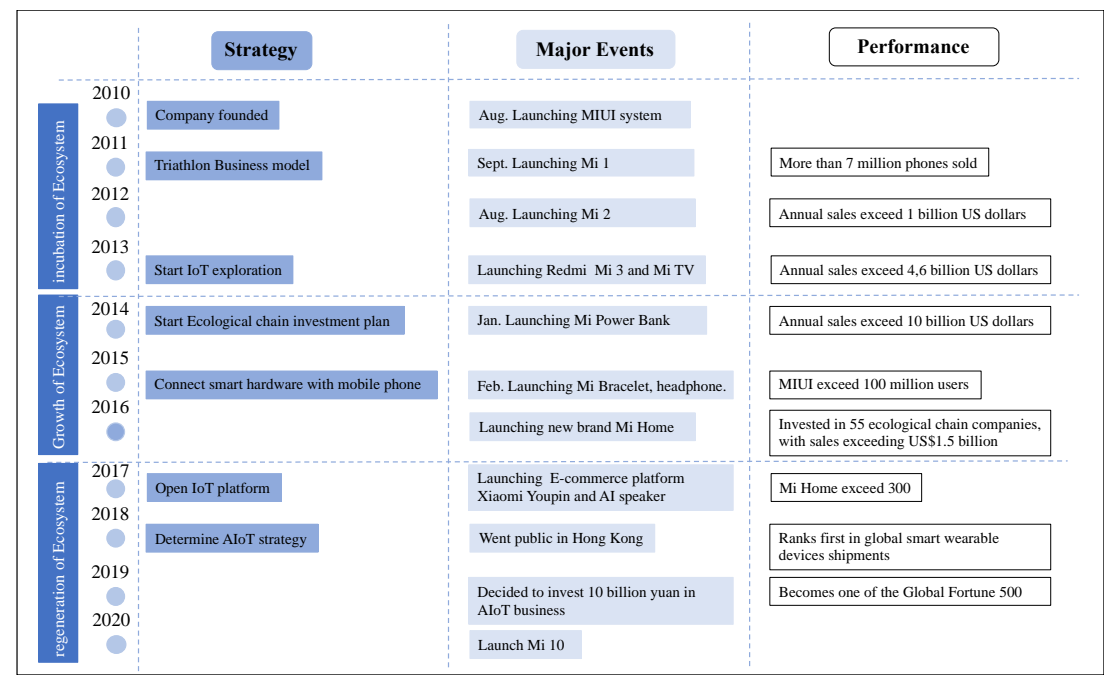

Figure 2. Landmark events in the evolution of Xiaomi's innovation ecosystem. 


\subsection{Phase 1: Incubating Innovation Ecosystems in Response to Mobile Internet (2010-2014)}

2010 is the first year of smartphones, heralding the transformation from PC Internet and feature phone to mobile Internet and smartphone. In 2010, China's smartphone market was dominated by smartphone brands such as Apple, and copycatting phones with low performance and prices. iPhone 4 initiated a wave of replacing keyboard phones with touch screen ones. However, there were not many touch-screen smartphones available on the market except for Apple and Samsung. As illustrated by the following quote, Lei Jun rekindled enthusiasm for starting a company in 2010 to meet middle and low-end consumer demands and promote the upgrading of smartphones.

Mobile Internet is about the experience brought by the integration of hardware and software. After visiting almost all the terminal manufacturers in China, I feel that no one is good enough.

- CEO of Xiaomi

Therefore, Lei decided to enter the market of mobile Internet with cellphones as a breakthrough. Lei and the other seven co-founders established Xiaomi. The companies' early products were targeted at mobile phone geeks. It launched the first product, MIUI mobile phone operating system, which was developed based on Android, and continuously improved the system according to users' feedbacks. Based on MIUI, Xiaomi began to develop mobile phones in July 2011 and sold them online at a very low price.

Opportunities and business model innovation led to a strong rise of Xiaomi in the market. Its annual revenue reached 550 million yuan in 2011, 12.65 billion yuan in 2012, and 31.6 billion yuan in 2013. In 2014, the corporation registered annual revenue of 74.3 billion yuan, topped China's phone market, and became the world's second-most highly valued startup at a $\$ 45$ billion valuation. At the same time, MIUI rapidly attracted more than 100 million users around the globe and tens of millions of Mi fans participated in the corporation's technological upgrading.

\subsection{Phase 2: Developing Innovation Ecosystems with an Eye to IoT (2014-2017)}

As smartphones became widely used, China's cellphone market became saturated. Decreasing cellphone dividend and a bottleneck in the Internet market scuppered Xiaomi's plan for selling 80 million cellphones in 2015. It was questioned that Xiaomi would reproduce the glory.

After serious reflection, Lei concluded that in response to the trend of IoT, Xiaomi needed to enrich the types of its products and expand offline channels. To rapidly access the IoT market, Xiaomi officially launched its IoT strategy. Xiaomi has established an ecological chain department, which on the one hand provides resources (investment and finance, drainage, channels, supply chain, etc.). On the other hand, manages the ecological order, allocates resources, and incorporates ecological chain products under their own brand "Mijia", to improve cooperation between Xiaomi and grow brand recognition. Through "investing in and incubating" companies in its ecosystem, the corporation expanded its product scope to include mobile phone peripheral products and smart devices. Xiaomi successfully applied its high-efficient development pattern to other product fields while maintaining focus on its core businesses such as mobile phones. Gradually, Xiaomi extended its product range from mobile phones to mobile phone peripheral products such as headphones and portable power banks. On this basis, the corporation leveraged its resources to invest in and incubated smart device companies (furniture and home accessories and safety \& security).

"Traditionally, a company is like a pine tree which needs decades to grow up. In the Internet era, a company is like bamboo that can spring up overnight. We invested in ecosystems as if we looked for bamboo shoots through investment. We transformed Xiaomi from a "pine tree" to a "bamboo" that can achieve self-improvement and sustainable development." 
In 2016, to break the bottlenecks of e-commerce and expand distribution channels, Xiaomi entered the offline retail market by opening up Mi Home, creating a retail model for high-frequency consumption through abundant SKU.

In 2017, the global shipment of Xiaomi's mobile phone reached 92.4 million and the sales of products on the ecosystem surpassed 20 billion yuan. Meanwhile, Xiaomi's products won all three major industrial design awards in China, namely Industrie Forum Design, Good Design Best 100, and Red Dot Design Award. The corporation set up $235 \mathrm{Mi}$ Home. It took only seven years for Xiaomi to achieve its annual sales target of 100 billion yuan. Thanks to success on the mobile phone, ecosystem, and Mi Home, Xiaomi became the only Internet brand that took a turn for prosperity after a decline in sales in China.

\subsection{Phase 3: Regenerating Innovation Ecosystems in Preparation for AI + IoT (2017-Now)}

The era of AI offered great opportunities for IoT development. After three years of development, Xiaomi became the world's largest smart hardware platform with systems of hardware products, big data, and ecosystem, marking staged success. To offer everyone convenient access to smart devices, Xiaomi further expanded its product scope and tried to enable AI on its products. Meanwhile, with eyes on future consumption upgrade, Xiaomi started to invest in daily consumables such as toothbrush and towels.

$\mathrm{AI}+\mathrm{IoT}$ was increasingly recognized by the industry as the mainstream in the future. For the integration of third-party products and Xiaomi's IoT products, Xiaomi rolled out AI Speaker. This first strategic AI product, combined with other products, constitute an ecosystem of household products.

"When developing and using AI technologies, Xiaomi created two AI ecosystems with a smartphone and AI Speaker as the respective focus. 'Mobile phone + IoT' means infinite AI development, while AI speaker will become an AI voice assistant accompanying us everywhere."

\section{-Chief Software Architect of Xiaomi}

At the MIDI Xiaomi IoT Developer Conference in November 2017, Xiaomi announced the opening of its IoT developer platform and strategic cooperation with Baidu to jointly establish an "AI + IoT" ecosystem integrating hardware and software and innovate AI products. At the 2018 AIoT Xiaomi developer conference in November, Xiaomi announced "AI + IoT" as its core strategy for the next decade, pledging to further open up its MACE and AI platforms and invest 100 million yuan to set up the "Xiaomi AIoT Developer Fund" to support more developers, hardware manufacturers, and AI companies.

"Xiaomi is not only an internet company but also a big data and AI company. AI technologies have broad application prospects in Xiaomi. From Automatic Speech Recognition (ASR) to NLP/NLU and deep learning, almost all the AI technologies are likely to be applied in different industries. More importantly, once a kind of technology is applied to one product, it could be used in a dozen products. Xiaomi is also among the most promising company that enables AI technologies to serve numerous users."

- Chief Software Architect of Xiaomi

Xiaomi launched two new AIoT products at the conference, namely Mi Home Smart Door Lock and AI Bluetooth Speaker. The corporation also expanded to the fields of home decoration, business travel, and automobile, promoting the application of AI technologies.

"IKEA intelligent lighting products will be connected to Xiaomi IoT platforms in December to support Mi Home App and the voice control of AI Speaker. This is the first time IKEA has cooperated with a Chinese tech company." 
To promote the development of Xiaomi's artificial intelligence technology and communicate with third-party companies, Xiaomi has set up the IoT platform department, the artificial intelligence department, the cloud platform department, and the big data department (see Figure 3), so to enable the IoT platform through AI and further expand the influence of Xiaomi's IoT platform. Besides, Xiaomi launched Xiaomi Youpin, an open e-commerce platform in April 2017. As an important part of Xiaomi's "new retail strategy", Xiaomi Youpin provides a platform for Xiaomi's private brands and ecosystem products. This further expanded Xiaomi's product scope and enabled household products to have the same level of price-quality ratio as Xiaomi's other products.

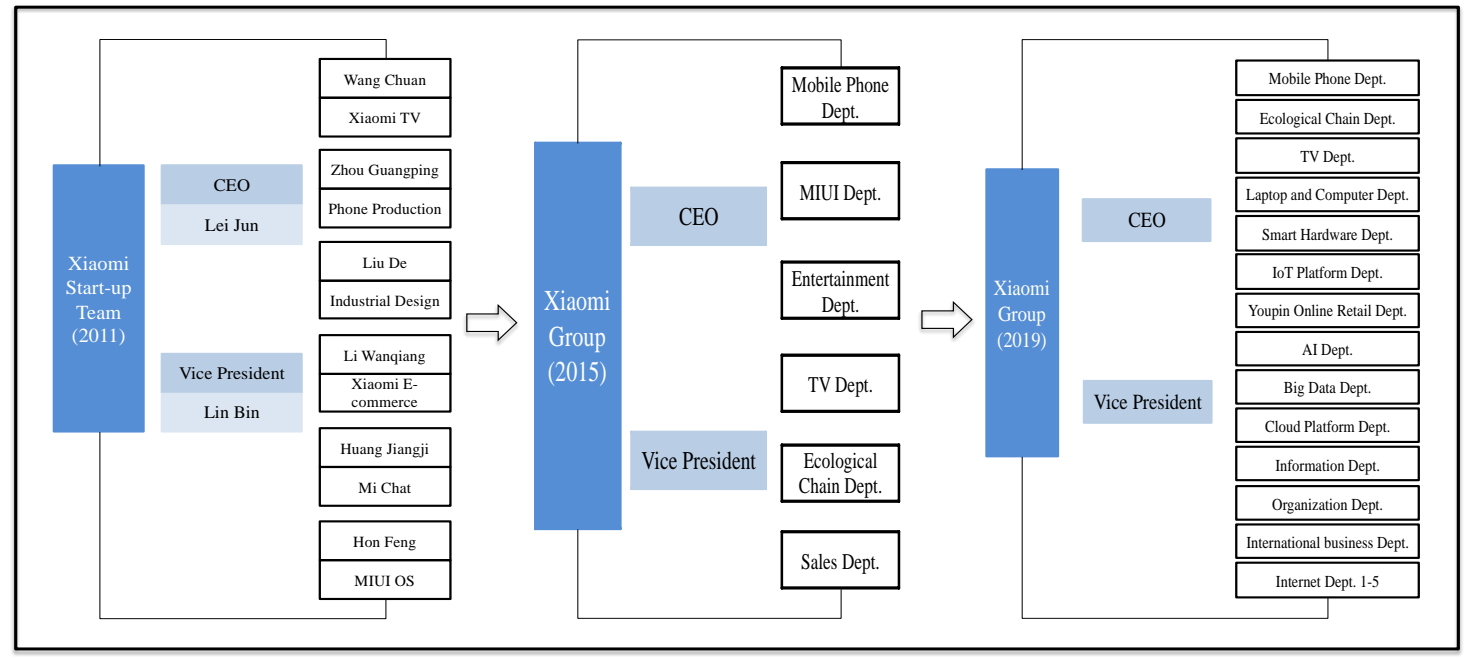

Figure 3. The evolution of Xiaomi's organizational structure.

As of 2019, the number of smart hardware devices connected to the Xiaomi IoT platform has reached 234 million, AI + IoT generated a revenue of 28.8 billion yuan. Xiaomi's smart speakers Xiao Ai have been awakened 8 billion times by users to activate around 100 million devices. Xiaomi forged a partnership with more than 400 companies, including Siemens and Philips, and announced a strategic cooperation with IKEA, Leading Ideal, and All Seasons Hotel. With products from more than 100 third-party brands sold on it, Xiaomi Youpin registered over 1 billion yuan in annual revenue. Thanks to the efforts of more than 8000 developers on Xiaomi's AI open platform, Xiao Ai, with more than 1300 skills, became one of the most active voice assistants in the world.

\section{Discussion}

Consistent with the previous study that describes the development of innovation systems into different stages [3], the development of Xiaomi's innovation ecosystem can be divided into three stages: (1) the incubation stage during which Xiaomi accumulated users and resources by adapting to mobile internet and focusing on its core products such as smartphone; (2) the growth stage during which Xiaomi started IoT business and developed mobile phone peripheral products and smart hardware, thus entering the manufacturing industry and achieving the integration of online and offline channels; and (3) the regeneration stage during which Xiaomi prepared AI + IoT, expanded to the area of daily consumables, forged cooperation with other companies, thus covering all the scenes of consumption and enabling AI on its products. Next, we describe each stage in detail.

\subsection{Analysis of the Development Pathway of Innovation Ecosystems}

Technological progress and the development of terminal equipment enable the "physical world" of a single object and one-way connection into an AI-based era of IoT, where a connection can be automatically established between people and objects as well as among objects themselves. Mobile Internet business differs from IoT business in user needs, technological drivers, 
product characteristics, and corporate ecosystems (see Table 2). An innovation ecosystem can not only create value through continuous investment from all parties but also achieve sustainable development through value sharing $[65,66]$.

Table 2. Differences between Xiaomi's Mobile Internet business and IoT business.

\begin{tabular}{cccc}
\hline Stage & Mobile Internet & IoT & AI + IoT \\
\cline { 2 - 4 } External Drivers & $\begin{array}{c}\text { Personalized services, } \\
\text { access information } \\
\text { anytime, anywhere }\end{array}$ & $\begin{array}{c}\text { convenient experience, } \\
\text { controlling other objects } \\
\text { through core objects }\end{array}$ & $\begin{array}{c}\text { smart experience, automatic } \\
\text { connection and interaction } \\
\text { between people and objects }\end{array}$ \\
\cline { 2 - 4 } & $\begin{array}{c}\text { Technological Drivers } \\
\text { mobile communication, } \\
\text { blue tooth, GPS }\end{array}$ & $\begin{array}{c}\text { radio frequency } \\
\text { identification, sensor } \\
\text { technology, wireless network }\end{array}$ & AI, cloud computing, big data \\
\cline { 2 - 4 } Internal Features & Product Characteristics \\
\cline { 2 - 4 } & product, no connection & $\begin{array}{c}\text { smart hardware, multiple } \\
\text { products, Internet of } \\
\text { everything }\end{array}$ & $\begin{array}{c}\text { interactive products, ubiquitous, } \\
\text { smart connection of everything }\end{array}$ \\
\cline { 2 - 4 } & & Corporate Ecosystems & \\
\cline { 2 - 4 } & closed business entities & closed business ecosystems & $\begin{array}{c}\text { open and cooperative } \\
\text { business ecosystems }\end{array}$ \\
\hline
\end{tabular}

\subsubsection{Incubation Period of Innovation Ecosystems: Focusing on Core Products}

With the arrival of the mobile Internet and a new era of smartphones, Xiaomi developed MIUI operating system and smartphone to enter the mobile phone market. Adopting a low-cost Internet model, Xiaomi produced mobile phones with high quality and low prices. Xiaomi's mobile phone won popularity among consumers, leading to a surge in their sales. The success of smartphones not only opened up upstream and downstream channels for the corporation, but also laid a foundation for the production and sales of Xiaomi's other products as well as the establishment of the whole ecosystem.

\subsubsection{Growth Period of Innovation Ecosystems: Developing Related Products}

Developing Products Closely Related to Mobile Phones

In response to the application of smart hardware, the trend of IoT, and the lack of a variety of featured innovations, Xiaomi decided to incubate ecosystem companies. Xiaomi invested in the products closely related to mobile phones, which is viewed at the start of its ecosystem. When developing innovations, a company makes use of relevant experience and leverages existing resources $[67,68]$. Based on the technologies and resources of its smartphones, Xiaomi quickly developed its first ecosystem product, the power bank. Such successful practices were then applied to develop other products such as Mi band and headphones.

Previous studies highlight the importance of the common goals shared by participants of innovation ecosystems and mutual dependence between them [40]. During the early growth phase, Xiaomi collaborated with ecosystem companies in developing mobile phone peripheral products for the maximal benefits of the ecosystem. Ecosystem products and core products interacted and reinforced with each other, laying a solid foundation for the future development of the innovation ecosystem.

Developing Products Loosely Related to Mobile Phones

During this phase, Xiaomi developed the products loosely related to mobile phones. The saturation of consumer demands and the bottlenecks in online channels prompted Xiaomi to develop IoT strategies. At the 2015 IoT Developer Conference, Xiaomi disclosed its IoT strategy for the first time-to connect all devices with mobile phones and apply Xiaomi's model to 100 segmentations, 
thus achieving product differentiation and promoting the development of the whole smart hardware field. Meanwhile, Xiaomi actively developed offline channels, with Mi Home built around the world. The corporation established an ecosystem of more than 270 companies, 90 of which dedicated to developing smart hardware.

Additionally, the mobile phone was the central control equipment of the Xiaomi IoT platform and Mi Home APP connected all the hardware devices. Hence, it functions as a dynamic control platform for the innovation ecosystem [41]. Xiaomi constantly enriched the types and connotations of its products, and increased the values of both core and ecosystem products, thus achieving the growth of its innovation ecosystem.

\subsubsection{Regeneration Period of Innovation Ecosystems: Developing Unrelated Product}

As Xiaomi's ecosystem reached a certain scale, its market restricted its development. For the sustainable development of the ecosystem, Xiaomi went beyond industry boundaries and integrated different industry chains. The corporation invested in daily consumables to make its product lines more diverse and focused, hedging against the uncertainties of tech companies. At the same time, Xiaomi fully opened up AI empowerment and planned to cooperate with the ecosystem and third-party companies to enable its products to meet 80 percent to 90 percent of needs in consumption scenes.

During the regeneration period, Xiaomi paid attention to cross-industry fields and made long-term investments to expand the boundaries of its innovation ecosystems. The corporation extended its product scope beyond mobile peripheral products to include smart hardware and finally daily consumables. Following this path (see Figure 4), Xiaomi gradually forged cooperation with a group of promising innovative technology companies, enriching innovation ecosystems and creating several listed companies. A previous study proposes effective vertical integration in the same industry as a strategy to manage interdependence between the hub firm and the upstream and downstream companies [5]. Our findings extend this view by showing that cross-industry exploration and collaboration help to enrich the diversity of the innovation ecosystems.

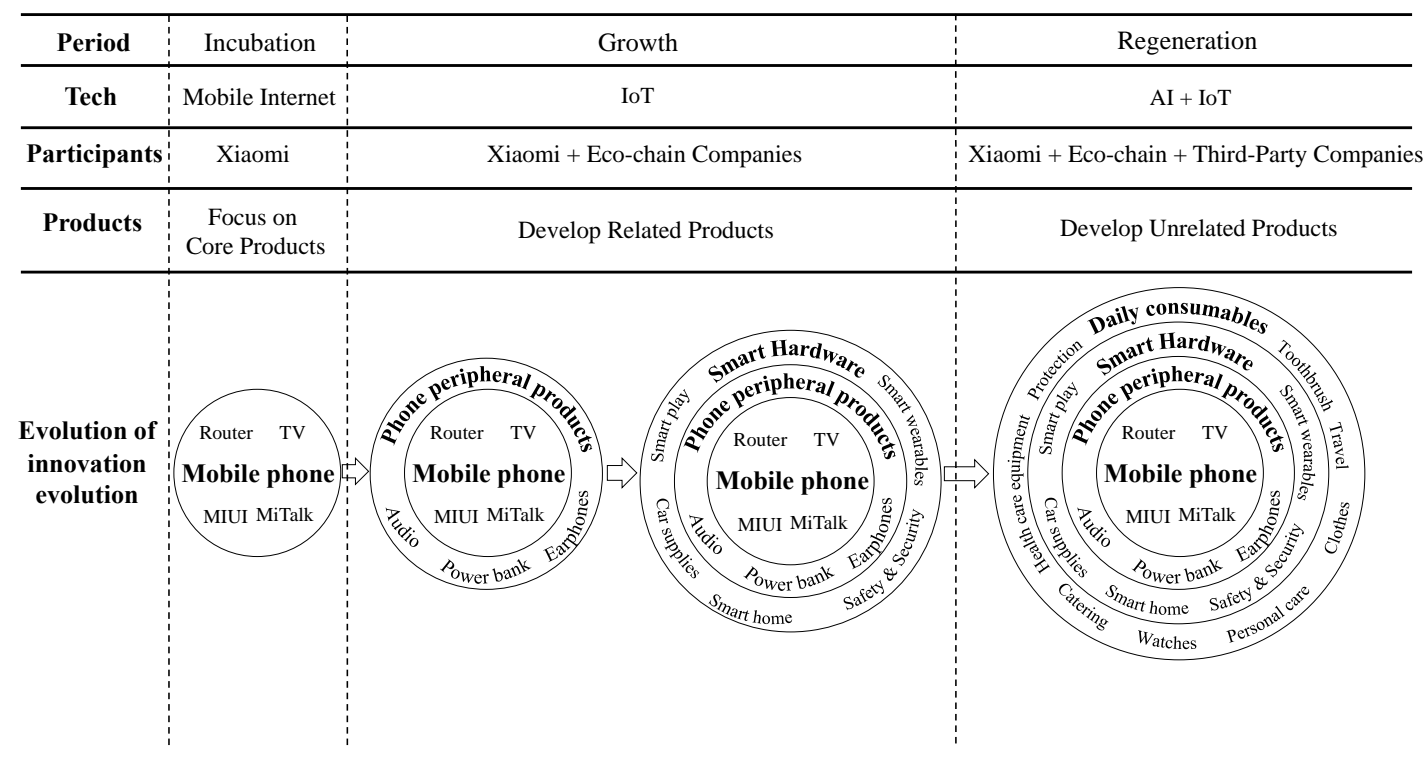

Figure 4. Evolution path of Xiaomi's innovation ecosystem.

\subsection{Internal Mechanism of Innovation Ecosystems}

Managers play a fundamental role in promoting development and improving the dynamical capabilities of a company. Their perception and cognition have a direct impact on the company's strategic transformations and successful adaption to changing environments [50]. 


\subsubsection{Internal Mechanism of Incubation Period}

Faced with the arrival of mobile internet and the rapid development of China's mobile phone market, Lei Jun realized that an era of smartphones had already come, but there was a gap in China's market. Lei led Xiaomi's senior management team to analyze the market and formulate multi-dimensional strategies to seize the opportunities and boom the development of the corporation.

"To verify the opportunities mentioned by Mr. Lei, we conducted surveys and observation, and discussed the market situation together."

\section{-Vice President of Xiaomi}

Previous research indicates that entrepreneurs play a dominant role in the development of a company at the early stage [17]. Entrepreneurs passively perceive the existing environment and provide cognitive support for product innovation and ecosystem evolution [69]. Besides, Vecchiato [70] highlights that managerial perception about customer needs directs the search for new markets and product opportunities. To solve the problems identified in the market, Lei defined mobile phone as Xiaomi's core product and charted the course for future development. His plan for Xiaomi's development drove the senior management team to realize that winning consumers' recognition was the key to success at that stage. Hence, Xiaomi needs to do its best to develop a mobile phone business. Guided by such cognition, Xiaomi focused on mobile phone development, built an internet business model, and laid out strategic principles of "remaining focused, doing best and acting swiftly".

"At the very beginning, Mr. Lei decided to follow a different path and deliver good quality products at reasonable prices. He developed Xiaomi's business model and we allocated personnel and resources accordingly."

-Marketing Director of Xiaomi

Because of its good quality and reasonable price, Xiaomi's smartphone, with a slogan of "born for fever", had led the market since its launch. To achieve the vision of "enabling everyone to enjoy the pleasure brought by technologies", the senior management team built up authority through speeches and also developed a corporate culture to improve organizational flexibility, thus reducing resistance to the growth of the innovation ecosystem.

"Xiaomi holds various events such as team-building activities to help us approach senior managers. We also read books about Xiaomi's development to gain a better understanding of our company and integrate ourselves into its culture."

\section{-Staff of Xiaomi}

During this period, the senior management team reached a consensus on entrepreneurs' cognition, which promoted a series of strategic transformations and incubated an innovation ecosystem around a single core product. In this way, Xiaomi accumulated capacities and resources, laid a firm foundation, and key position for its future development of innovation ecosystems [71].

\subsubsection{Internal Mechanism of Innovation Ecosystem's Growth Period}

\section{Early Growth Phase}

The arrival of IoT led to the dividend reduction of mobile phone users and fierce competition. Lei Jun alerted that the mobile phone market was saturated at that time and diversified businesses can ensure the sustainable development of the company. The company's top management also realizes that they should start with products that are closely related to the core products to use existing resources and capabilities and improve user acceptance. After many rounds of discussions, they established an IoT strategy for the ecosystem business, starting from the mobile phone peripheral products. Such a process reflects the importance of the two distinct yet complementary cognition of the top management team in influencing a firm's strategy [72]. 
"Mr. Lei saw the decreasing trend of mobile phone dividend and began to think about the future development direction of the market. At the front line, we also clearly experienced the trend that hardware will be more equipped with sensors and become more digitized in the future. It will involve a variety of products. We sorted out the market data and gave feedback to Mr. Lei".

-Vice President of Ecosystem

Studies found that the recognition of the senior management team at this stage actively forecasts market trends, provide a foundation for the growth and development of innovation ecosystems [73]. Based on the forecasted market developing trend, Lei Jun realized that the key to ensuring a smooth transition of Xiaomi's operation is to coordinate the company's original advantageous business with the newly-developed business. After the discussion, executives decided to extend the mobile phone peripheral products by adopting the model of investing and incubating ecosystem company, setting up a new ecosystem department, and promoting interaction and integration of the original and the new businesses.

"The biggest challenge is how to integrate Xiaomi and ecosystem companies. For this reason, we have established an ecosystem department, which has copied the model of Xiaomi with personnel transferred from the senior management team and shared resources to the ecosystem companies. We only hold a certain percentage of shares. This improves the efficiency of the ecosystem companies greatly."

—General Manager of Xiaomi

At the same time, Lei Jun stressed the need to form the unique values of Xiaomi, and insisted on making good products that are "touching and inexpensive". Under the leadership of Lei Jun, the top management actively advocated high-level exchanges and learning, conveyed the values of Xiaomi to achieve unified employee recognition, and conformed to the new business of the ecosystem to reduce resistance to changes.

"We often organize meetings to convey the values of Xiaomi. We have set up a quality control department to keep Xiaomi style for the appearance and connotation of ecosystem products, and have unified the supply and marketing channels to ensure product quality and maintain the brand image of Xiaomi."

—Marketing Director of Xiaomi

Late Growth Phase

With the increasing consumer demand for difference and experience, as well as the blurring boundaries between online and offline channels, Lei Jun realized that the growth bottleneck of e-commerce began to emerge. Executives believed that e-commerce had never found a realistic path that provided a good shopping experience. After fierce discussions, the senior management team decided to adopt the "new retail" model to start the upgrade of consumer shopping experience and build an omnichannel ecosystem pattern to achieve breakthroughs.

"As the difference between online and offline prices is reducing, Mr. Lei and our front-line employees believe that consumers have an increasingly urgent demand for offline stores, which is also confirmed by our market research. Therefore, we've begun to collect consumers' demand for our products and conduct internal tests on some products. We make decisions on whether to develop a new product based on the market feedback."

—Marketing Director of Xiaomi

With further development of an innovation ecosystem, the senior management team relies on practical experience to address the limitations of managerial cognition [74]. At this stage, there was an active exploration-based cognition of potential consumption points in the market to obtain advantages 
of the first entrants. Previous studies indicate that managerial cognitive capabilities improve the response strategy and performance of the top management team [75,76]. In response to the urgent needs of consumers, managers carry out heuristic processing and quickly design solutions [77]. Lei Jun decided to explore smart hardware to enrich the offline channels, and the executives suggested further extending Internet services to improve user stickiness. The triathlon business model of "hardware + new retail + Internet" combination was formulated, the mobile phone platform was used to realize the connection of things, and user coverage was expanded through omnichannel new retail.

"After rapid development, we entered the adjustment period and began to think about management refinement and expand our businesses. The triathlon model guides us to a leading mobile phone business and a large number of cost-effective smart hardware. The development of online and offline channels further improves our competitive advantage."

\section{—General Manager of IoT Platform}

Besides, the top management team promoted the establishment of an internal communication system, expanding and internalizing high-level understanding into the awareness of the entire ecosystem, thereby strengthening the leading role of core enterprises and promoting mutual feedback between superiors and subordinates to help the management and employees overcome cognitive sluggishness and inertia. At the same time, Xiaomi's core leadership has shown a high sensitivity to strategic opportunities and made a correct judgment to form a good authoritative image.

"Xiaomi has a three-layer organizational structure, which is very flat. The executive meeting is held at 6:00 PM every Monday... We often communicate with our employees, including the ecosystem companies, sometimes ten or twenty times a day. We also communicate with each other by phone to solve problems at any time. They trust us very much."

—Vice President of Xiaomi

Based on the mutual support and coordination of entrepreneurs and senior teams, Xiaomi has realized the connection of things in incubating smart hardware and has strengthened the leadership in the development direction of the ecosystem to improve competitive advantage and further consolidate the market position.

\subsubsection{Internal Mechanism of Innovation Ecosystem Regeneration Period}

Research shows that the evolution of the innovation ecosystem might be driven by technology changes [78]. In our case, technology continues to evolve, and the product life cycle is shortened. Lei Jun realized that the market was changing rapidly and whether the company can compete successfully depends on the timely launching of innovative technologies and products. The executives realized that whether new products can be launched promptly depends not only on Xiaomi and ecosystem companies but also on their cooperation with third parties. Based on the trend of the Internet of Things, the top management team realized that product expansion and open cooperation are effective strategies to deal with consumption upgrade.

"We have seen the trend of AI + IoT. Not only does Xiaomi need to do well, so does everyone. Open cooperation is the only way to achieve innovation. We offer solutions to Mr. Lei to help him make relevant strategies."

—General Manager of IoT Platform

Studies found that with further expansion of the innovation ecosystem, the senior team has accumulated rich practical experience and coping strategies [79]. The expansion of the company made it difficult for entrepreneurs to know the diversified and complex situation of companies promptly. Therefore, the senior management team needed to work together to encourage entrepreneurs to 
renew themselves and improve their perceptions. Such understanding provided a cognitive basis for stabilizing the market in the future. According to their understanding of the future trend, managers conduct controlled treatment, think broadly, and collect solutions at a wide range [77]. The management team of Xiaomi decided to expand new categories of daily consumables, developed the core strategy of AI + IoT, reduced AIoT cost, loosened control over IoT platform and resources, and provided platform support for the ecosystem and third-party enterprises. At the same time, they achieved global strategic cooperation with companies such as IKEA to realize AI technology. Additionally, they have built a network with smartphones, consumer IoT, new retail industries, and platform value to enhance competitiveness.

"You may think that Xiaomi is a software or hardware company. It is a platform company combining all aspects of everyone. Its self-expansion ability is like a communicator, and it has waves of self-growth."

- CEO of Xiaomi

"The competition of AI will eventually be a competition of open ecology. We will continue to work together with our partners to create a bright future for AIoT, adhering to the open and win-win principle."

—Vice President of Xiaomi

Besides, Lei Jun created an organizational environment of "inheritance and innovation" to continuously develop and improve products, follow the tradition of the original business, and adapt to new demands of market changes. Research shows that complementary components, assets, and platforms nurtured the innovation ecosystem [80,81]. This is also true in our case in that the senior management team actively encouraged the introduction of outstanding talents, and business exchanges and cooperation to help employees adapt to new business and lay a foundation for the smooth implementation of new strategies.

"We have been rethinking and summarizing our experience, and we are constantly exploring the future development. This is not only what executives should do, but employees of the company need to have this sense of ownership."

\section{—Vice President of Ecosystem}

As a result, the senior management team continuously promoted the improvement and development of entrepreneurs' cognition. Guided by technology and market changes, and employing business diversification and integration of online and offline channels, the original core competence is copied to different consumption areas to continuously improve product and user scale. Extant studies indicate that the architectures of different innovation ecosystems are becoming more complicated and they call for more research in exploring different architectures [82]. Our case answers this call by showing that, with the transformation from the core products to the product groups involved in multiple scenarios, the innovation ecosystem transformed from a single sphere composed of core products to a multi-layered sphere supported by multiple products, thus achieving a systemic competitive advantage that can help to realize the sustainable development of the company (see Figure 5).

\subsection{Intrinsic Driving Force of Innovation Ecosystem-Managerial Cognitive Capability}

In this section, we focus on discussing how managerial cognitive capabilities drive the development of innovation ecosystems. Managerial cognitive capability refers to the mental process of managers with specific beliefs and mental models to process specific information based on the needs of decision making [13]. Managerial cognition crosses multiple levels and is influenced by educational background, experience, and professions [15]. Managerial cognitive capability forms the basis for decision making and action [47]. 


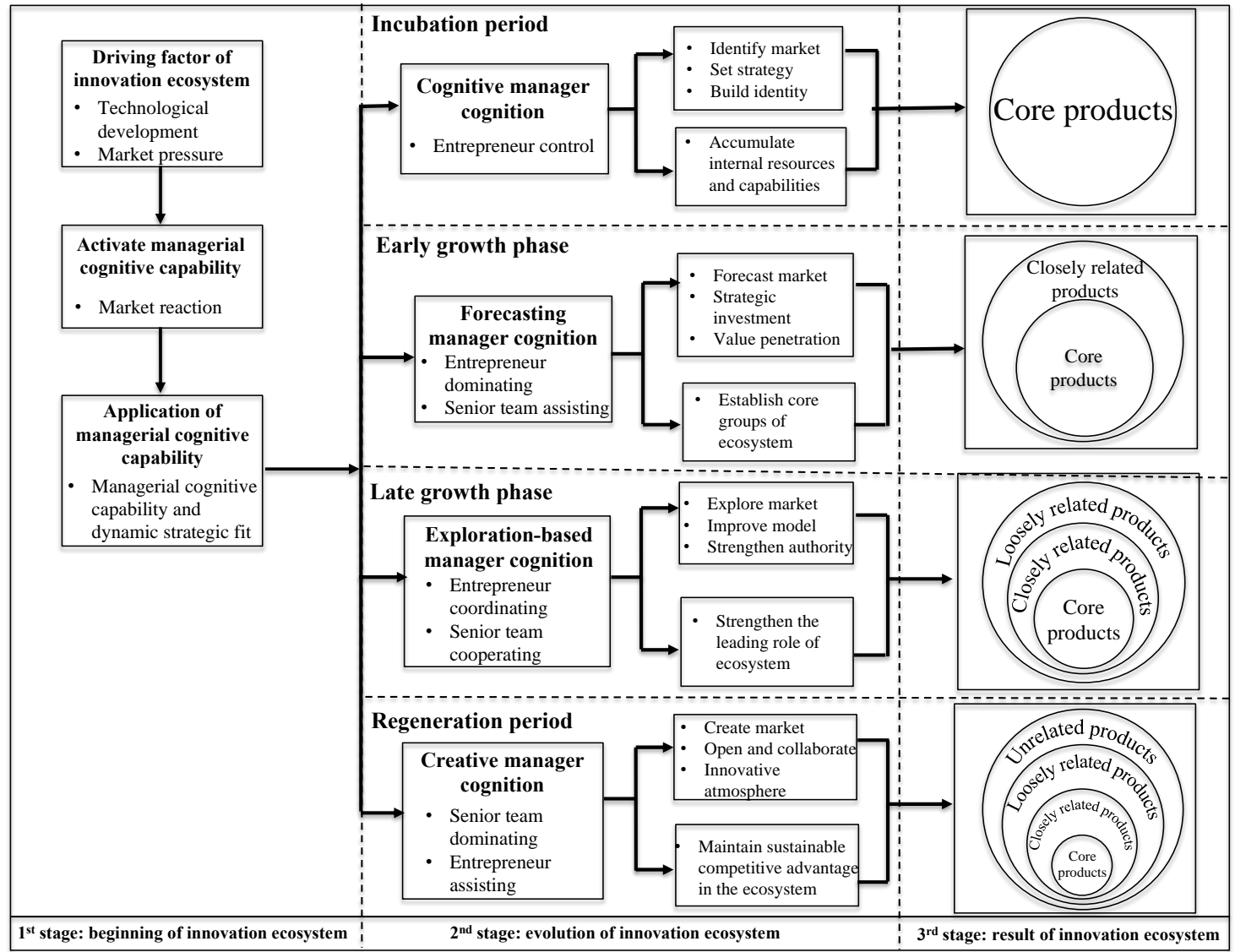

Figure 5. The role of managerial cognitive capability in the development of Xiaomi's innovation ecosystem.

\subsubsection{Components of Managerial Cognitive Capability}

\section{Entrepreneurial Cognitive Capability}

Lei Jun started to establish Sanse company in his senior year in college, and then worked in Kingsoft for 16 years as president, and entered the IPO market. Moreover, as an angel investor, he invested in more than 20 innovative companies such as joyo.com. Having been deeply engaged in IT and investment for several years, Lei Jun had accumulated a large number of contacts and formed "Lei Jun style" companies and a special investment fund system, which laid a foundation for the later establishment of Xiaomi, and the development of Xiaomi's innovation ecosystem. Lei led Xiaomi to collaborate with "investment + incubation" ecosystem companies.

"Indeed, Mr. Lei has more than 20 years of experience as an entrepreneur and he knows well about the product and technology. That's why Xiaomi can make it today. Mr. Lei is also an extreme perfectionist. He requires that all products must be exceptionally simple. He is also very broad-minded. The growth of this company has a lot to do with Mr. Lei."

\section{—Vice President of Xiaomi}

"I think the most fundamental reason why Xiaomi's model can be successful ... is about Lei Jun himself, and his dual identity as an investor and an entrepreneur."

\section{-General Manager of Xiaomi}

Previous studies highlight that the CEO's educational profile in management and technical background facilitates the strategic transformation and value creation process of the firm [83]. 
Our findings regarding Lei's experience with the development of Xiao's innovation ecosystem complement this view by showing that, in addition to personality traits and previous experience, managerial cognitive capability at the individual level is also influenced by related social networks [15]. Moreover, our findings also show that entrepreneurs make themselves have a cognitive model matching with the environment and promote their cognition to spread and penetrate in the senior management team, further push forward information exchange and integration to help the senior management team constantly innovate management methods, and ultimately accelerate the construction and development of relevant corporate practices in companies. Previous research generally studies the CEO or top management team's managerial cognitive capabilities separately $[84,85]$, our study complements this research stream by showing the role of the CEO's managerial cognitive capabilities in driving the development of top management team. Further, Consistent with Acciarini [86], our findings highlight that managerial cognitive capabilities and decision-making processes are also enabled by external factors.

\section{Senior Management Team's Managerial Cognitive Capability}

The composition of members in the senior management team influences the team's judgment on the market and strategies [87]. The long-term accumulated team culture and team atmosphere also affect the cultivation of the senior management team and the development of its cognitive capability [88]. The founding team of Xiaomi was composed of 7 people from leading IT companies such as Google and Microsoft, each specializing in a particular area such as industrial design and human-computer interaction. All of them had over 20 years of experience on average in leading IT companies globally. The senior team of Xiaomi advocated an efficient and fast Internet culture, created a partnership work environment, and achieved China's No.1 smartphone sales in three years under the condition of no experience in the hardware industry. Moreover, every founder had a strong desire to start a business, takes the founding of a great company as his dream, and had a clear sense of mission. They promoted the strategic layout of Lei Jun and carried out category extension and product innovation in a planned and orderly way. As Vice president said,

"Our founding team has never touched upon the mobile phone except for Dr. Zhou, who comes from MOTOROLA. They all work on software or do management work. However, it is in this way that we can achieve what we have done today. It is not that the layman killing the professionals, but the trend killing the tradition."

\section{—Vice President of Xiaomi}

Such a heterogeneous team has rich resources, diverse perspectives, and varied knowledge. Each member interacts and integrates and coordinates in various fields, helping the team make effective decisions and promoting the development of the innovation ecosystem. The team culture further unifies the will and behavior of employees. The strong innovation atmosphere of the team promotes the continued growth of the cognition of Lei Jun himself and Xiaomi's senior management team. Consistent with previous literature, in our case, the development of the managerial cognitive capabilities shows a positive impact on their seizing ability [89] innovation capacity [90], and business modeling, and partnering capability [91].

\section{Interaction Mechanism of Components}

Engler et al. [92] highlight that entrepreneurs learn and develop their knowledge and capabilities at different stages of market entry. Following their comments, our findings show that the power and influence of the CEO and the top management team changes as different entities learn and develop cognitive capabilities at different stages of innovation ecosystems. As decision-makers and managers of a company, entrepreneurs stand in the core position and play a key role. By implementing entrepreneurial activities, they influence the cognitive structure and process of senior teams and then guide the cognition direction of the team. Meanwhile, the cognitive capability of the senior team 
stimulates the individual's innovative spirit and provides a favorable environment for the development of entrepreneurial cognitive capability. With the development of the innovation ecosystem, the dominant position of individual entrepreneurial cognitive capability and senior teams' cognitive capability change, promoting the continuous improvement of managerial cognitive capability.

\section{Conclusions}

\subsection{Summary of the Findings}

In this study, we aim to explore the role of managerial cognitive capability in the development of a hub-based innovation ecosystem. Three important findings can be summarized in our case. First, the three types of managerial cognitive capability manifest themselves differently in the four phases of the innovation ecosystem and positively influence the development of the ecosystem. Second, the development of the innovation ecosystem also drives the development of managerial cognitive capability. Third, along with the development of the innovation ecosystem, the role of the CEO and the top management team changes from CEO controlling and top management assisting to top management dominating and CEO assisting. We now leverage existing literature in innovation ecosystems and managerial cognitive capability and case study examples to explicate the implications of the study.

\subsection{Theoretical Implications}

Three important theoretical implications can be drawn from our findings. First, while Helfat and Peteraf [15] propose the managerial cognitive capability as perception attention, problem-solving and reasoning, and social cognition, they manifested differently in the four phases of Xiaomi's innovation ecosystem. Their positive influence on the development of Xiaomi's innovation ecosystem confirms with previous literature in strategic management that managerial cognitive capabilities function as a micro foundation of dynamic managerial capabilities which further facilitate the strategic changes $[14,19,20]$. This also advances research in innovation ecosystems by answering the call for research that examine the effects of different content and structure of managerial cognitive capability on the sustainable development of the innovation ecosystem [17].

Second, our findings extend the view of the relationship between managerial cognitive capability and strategic change by showing that a firm's strategic orientation might also influence how CEO and top management team develop their managerial cognitive capability. The different manifestations of managerial cognitive capability might be attributed to the different strategic orientations in each phase. For example, in the second phase of Xiaomi's innovation ecosystem, it focusses primarily on developing a closely related product to its core product. Hence, its main strategic direction was to establish a core group. This required, for example, the CEO and top management team to penetrate its core value to its internal employees and external customers (value penetration). Hence, we contribute to related strategic management research $[15,21,22]$ by showing the mutual influence between managerial cognitive capability and strategic change. Additionally, previous research on hub-based innovation ecosystems highlights the critical role of management in developing and managing an innovation ecosystem $[8,10,18]$. Our finding complements this research by demonstrating that the evolution of the innovation ecosystem also drives the development of management.

Third, existing literate related to managerial capabilities highlights that managerial cognitive capabilities have a profound impact on corporate performance [13,93]. However, most studies focus primarily on individual entrepreneurs [15]. Little attention has been paid to the managerial cognitive capabilities at a group level. This paper takes "entrepreneurial cognition-senior team's cognition" as the basic path and clarifies the long-term two-way interactions between managerial cognitive capabilities and senior team's cognitive capabilities, and forms cross-level managerial cognitive capabilities through diffused penetration and incentive support. As shown in the case of Xiaomi's innovation ecosystem, with the development of the ecosystem, the dominant position of managerial cognitive capabilities 
and senior team's cognitive capabilities changes accordingly, thereby improving the development of managerial cognitive capability. Such implications not only enrich the theory of managerial cognitive capability but also provides a pattern for companies to develop an innovation ecosystem.

\subsection{Practical Implications}

In terms of practical implications, first, this research proposes a process model that describes the development of an innovation ecosystem, thereby providing an overall map illustrating how a hub firm develops from a single innovation to an innovation ecosystem. Besides, it reveals the growth path and the evolutionary mechanism of innovation ecosystems, providing a development model for hub firms in different stages of innovation ecosystems. Further, in the contemporary business world, markets and technologies are changing rapidly. Our findings emphasize that companies need to pay attention to the role of managerial cognitive capability and quickly identify changes in technology and market to carry out strategic redirection and seize opportunities to grow rapidly. Moreover, based on the market changes and their internal conditions in different periods, companies need to explore new areas based on core business, build their ecosystem, and realize sustainable competitive advantage in the long run. Finally, for hub firms that strive to develop innovation ecosystems, the management team needs to realize the mutual influences between their cognition and the evolution of the ecosystems. In particular, management teams should realize that, at the different stages of the innovation ecosystem, they need to develop different managerial cognitions.

\subsection{Limitations and Future Research Direction}

This paper studies the growth path and mechanism of the innovation ecosystem, reveals the internal mechanism of the development of Xiaomi's innovation ecosystem. While this study is insightful, is no free of limitations, several of which indicate future research directions. Particularly, the research site of this paper is a leading company in the Internet industry in China, but what about the managerial cognitive capability and innovation ecosystem evolution for small and medium-sized Internet companies and firms in other industries and other countries? To overcome the limitations of the single case study, researchers are also recommended to conduct in-depth research on more types of companies in the future, aiming at systematically approaching the phenomenon of innovation ecosystems. In particular, future research should apply the findings of the research to different countries, sectors, or different size companies, thereby further testing the generalizability of the findings.

\subsection{Concluding Comments}

In developing its innovation ecosystem, a hub firm faces the challenges brought by the constant strategic reorientations. Previous literature related to a hub-based innovation ecosystem has paid little attention to how the hub firm deals with such challenges. To fill this gap, we have conducted a case study of Xiaomi, whose top management team has demonstrated strong managerial cognitive capability in making strategic changes and adapting to the dynamic market. Our findings contribute to innovation ecosystems by showing not only the role of different managerial cognitive capabilities in developing innovation ecosystems but also the driving effects of innovation ecosystems on managerial cognitive capabilities. We also contribute to managerial cognitive capabilities by demonstrating the role of managerial cognitive capabilities in facilitating strategic changes as well as the mutual influence between managerial cognitive capability and strategic changes. Future research is recommended to build upon the preliminary findings of this study to further explore the relationship between managerial cognitive capabilities, strategic changes, and the development of innovation ecosystems.

Author Contributions: The authors contributed in the following ways: conceptualization, X.C., and T.O.; data curation, X.C. and S.Z.; formal analysis, X.C., P.B. and S.Z.; methodology, X.C. and S.Z.; project administration, T.O.; resources, T.O.; supervision, T.O. and S.Z.; validation, P.B.; writing-original draft, X.C., S.Z. and T.O.; writing-review and editing, P.B. All authors have read and agreed to the published version of the manuscript. 
Funding: This research was funded by the National Natural Science Foundation of China, grant number 71632003, 71972008, and 71901009.

Conflicts of Interest: The authors declare no conflict of interest.

\section{Appendix A}

Table A1. Xiaomi's representative ecological chain enterprise information.

\begin{tabular}{|c|c|c|}
\hline Company Name & Main Product & Established Time \\
\hline \multicolumn{3}{|l|}{ Mobile Phone Peripheral Area } \\
\hline ZMI Electronic & Phone accessories & 2012.02 \\
\hline 1MORE Technology & Xiaomi headphone & 2013.02 \\
\hline Anhui Huami Technology & Xiaomi Bracelet, Huami Watch & 2014.01 \\
\hline Qingmi Technology & Xiaomi patchboard & 2014.02 \\
\hline Lanmi Technology & Xiaomi Bluetooth headphone & 2014.04 \\
\hline Shuomi Technology & Phone case & 2015.03 \\
\hline Liesheng Electronic & Headphone, Speaker & 2015.05 \\
\hline Beijing Tianmi Technology & Mi Laptop Air & 2015.07 \\
\hline Moxiang Technology & VR/AR & 2016.05 \\
\hline Shangmi Technology & Smart commercial equipment & 2013.12 \\
\hline Beijing IQI Technology & Robot & 2015.11 \\
\hline QBORN Technology & Infant product & 2017.08 \\
\hline Xiaoxun Technology & $\begin{array}{l}\text { Mitu child watch, Xiaoxun child phone } \\
\text { watch and tablet }\end{array}$ & 2016.03 \\
\hline \multicolumn{3}{|l|}{ Smart Home Area } \\
\hline Fengmi Technology & Smart Projector & 2016.03 \\
\hline Qingmi Technology & \multirow{2}{*}{ Smart Home } & 2014.02 \\
\hline Chuangmi Technology & & 2014.04 \\
\hline Yunmi Technology & Small smart house electronics & 2014.05 \\
\hline Zhimi Technology & Air Purifier & 2014.06 \\
\hline Chunmi Technology & Smart cooker & 2013.07 \\
\hline Shenzhen Lumi Technology & Smart House & 2014.06 \\
\hline Hangzhou Yunyou Technology & Smart Door Lock & 2014.10 \\
\hline $\begin{array}{l}\text { Foshan Yunmi Electronic } \\
\text { Technology }\end{array}$ & Xiaomi water purifier, water TDS tester & 2015.01 \\
\hline Beijing Shitou Shiji Technology & Mi Cleaning robot & 2015.09 \\
\hline Qiezi Technology & Smart home and health devices & 2017.03 \\
\hline Moxiang Technology & VR, AR devices & 2016.08 \\
\hline $\begin{array}{l}\text { Xi'an Musheng Electronic } \\
\text { Technology }\end{array}$ & Xiaomi Mi Home intercom & 2016.03 \\
\hline Yi Technology & Wearable video devices & 2014.09 \\
\hline
\end{tabular}


Table A1. Cont.

\begin{tabular}{|c|c|c|}
\hline Company Name & Main Product & Established Time \\
\hline Shanghai Chuangmi Technology & $\begin{array}{l}\text { Xiaomi Smart camera, Xiaomi Internet } \\
\text { radio, Xiaomi remote control, Xiaomi } \\
\text { smart connector, Xiaomi Fitness }\end{array}$ & 2014.12 \\
\hline Beijing Fengmi Technology & Laser TV & 2017.03 \\
\hline Shukeshi Technology & Sushi Sonic electronic toothbrush & 2017.03 \\
\hline \multicolumn{3}{|l|}{ Medical Health Area } \\
\hline iHealth & iHealth & 2014.09 \\
\hline Miaomiaoce & Smart Body thermometer & 2016.12 \\
\hline Soocas & Personal health care & 2017.03 \\
\hline Jienaituo Technology & Optical glasses & 2017.03 \\
\hline \multicolumn{3}{|l|}{ Car Accessories Area } \\
\hline Banya Technology & Car Electronics & 2016.03 \\
\hline Ruimi Information & Smart car devices & 2015.01 \\
\hline Yunzao Technology & Foldable scooter & 2013.07 \\
\hline Ninebot & Balancing scooter & 2013.09 \\
\hline Checaiduo & Transportation & 2017.12 \\
\hline Chemi Information Technology & Smart car & 2016.02 \\
\hline $\begin{array}{l}\text { Guangzhou Feilai Electronics } \\
\text { Technology }\end{array}$ & Xiaomi drone & 2014.05 \\
\hline CareDear & 21KE phone & 2014.06 \\
\hline QiCYCLE & Foldable electric bike & 2015.02 \\
\hline \multicolumn{3}{|l|}{ Children Area } \\
\hline IQI Technology & Education robot & 2013.04 \\
\hline Xiaoxun Technology & Child electronic devices & 2015.07 \\
\hline Jiqidao Technology & Child companion robot & 2016.01 \\
\hline \multicolumn{3}{|l|}{ Life consumables area } \\
\hline Zuishenghuo & Towel & 2016.05 \\
\hline Qushui Technology & $8 \mathrm{H}$ Latex mattress & 2015.12 \\
\hline Xiaobei Technology & Oral care products & 2016.12 \\
\hline
\end{tabular}

\section{References}

1. Nambisan, S.; Wright, M.; Feldman, M. The digital transformation of innovation and entrepreneurship: Process, challenges and key themes. Res. Policy 2019, 48, 103773. [CrossRef]

2. Boyer, J. Toward an evolutionary and sustainability perspective of the innovation ecosystem: Revisiting the panarchy model. Sustainability 2020, 12, 3232. [CrossRef]

3. Gan, J.; Qi, Y.; Tian, C. The construction and evolution of technological innovation ecosystem of Chinese firms: A case study of LCD technology of CEC panda. Sustainability 2019, 11, 6373. [CrossRef]

4. Moore, J.F. Predators and prey: A new ecology of competition. Harv. Bus. Rev. 1993, 71, 75-83.

5. Adner, R.; Kapoor, R. Value creation in innovation ecosystems: How the structure of technological interdependence affects firm performance in new technology generations. Strateg. Manag. J. 2010, 31, 306-333. [CrossRef]

6. Iansiti, M.; Levien, R. The Keystone Advantage: What the New Dynamics of Business Ecosystems Mean for Strategy, Innovation, and Sustainability; Harvard Business Press: Boston, MA, USA, 2004. 
7. Nambisan, S.; Baron, R.A. Entrepreneurship in innovation ecosystems: Entrepreneurs' self-regulatory processes and their implications for new venture success. Entrep. Theory Pract. 2013, 37, 1071-1097. [CrossRef]

8. Chaminade, C.; Randelli, F. The role of territorially embedded innovation ecosystems accelerating sustainability transformations: A case study of the transformation to organic wine production in Tuscany (Italy). Sustainability 2020, 12, 4621. [CrossRef]

9. Jiang, S.; Hu, Y.; Wang, Z. Core firm based view on the mechanism of constructing an enterprise innovation ecosystem: A case study of Haier group. Sustainability 2019, 11, 3108. [CrossRef]

10. Botti, A.; Monda, A. Sustainable value co-creation and digital health: The case of trentino eHealth ecosystem. Sustainability 2020, 12, 5263. [CrossRef]

11. Wu, J.; Yang, Z.; Hu, X.; Wang, H.; Huang, J. Exploring driving forces of sustainable development of China's new energy vehicle industry: An analysis from the perspective of an innovation ecosystem. Sustainability 2018, 10, 4827. [CrossRef]

12. Zeng, D.; Hu, J.; Ouyang, T. Managing innovation paradox in the sustainable innovation ecosystem: A case study of ambidextrous capability in a focal firm. Sustainability 2017, 9, 2091. [CrossRef]

13. Adner, R.; Helfat, C.E. Corporate effects and dynamic managerial capabilities. Strateg. Manag. J. 2003, 24, 1011-1025. [CrossRef]

14. Zhang, Y.; Rajagopalan, N. Once an outsider, always an outsider? CEO origin, strategic change, and firm performance. Strateg. Manag. J. 2010, 31, 334-346. [CrossRef]

15. Helfat, C.E.; Peteraf, M.A. Managerial cognitive capabilities and the microfoundations of dynamic capabilities. Strateg. Manag. J. 2015, 36, 831-850. [CrossRef]

16. Yang, T.K.; Yan, M.R. Exploring the enablers of strategic orientation for technology-driven business innovation ecosystems. Sustainability 2019, 11, 5779. [CrossRef]

17. Lei, L.; Wu, X.; Fu, Y. Effects of sustainability and technology orientations on firm growth: Evidence from Chinese manufacturing. Sustainability 2019, 11, 4406. [CrossRef]

18. Tolstykh, T.; Shmeleva, N.; Gamidullaeva, L. Evaluation of circular and integration potentials of innovation ecosystems for industrial sustainability. Sustainability 2020, 12, 4574. [CrossRef]

19. Hermann, P.; Nadkarni, S. Managing strategic change: The duality of CEO personality. Strateg. Manag. J. 2014, 35, 1318-1342. [CrossRef]

20. Martin, J.A. Dynamic managerial capabilities and the multibusiness team: The role of episodic teams in executive leadership groups. Organ. Sci. 2011, 22, 118-140. [CrossRef]

21. Eggers, J.P.; Kaplan, S. Cognition and capabilities: A multi-level perspective. Acad. Manag. Ann. 2011, 7 , 293-338. [CrossRef]

22. Hodgkinson, G.P.; Healy, M.P. Psychological foundations of dynamic capabilities: Reflexion and reflection in strategic management. Strateg. Manag. J. 2011, 32, 1500-1516. [CrossRef]

23. Senyo, P.K.; Liu, K.; Effah, J. Digital business ecosystem: Literature review and a framework for future research. Int. J. Inform. Manage. 2019, 47, 52-64. [CrossRef]

24. Rong, K.; Hu, G.; Lin, Y.; Shi, Y.; Guo, L. Understanding business ecosystem using a 6C framework in Internet-of-Things-based sectors. Int. J. Prod. Econ. 2015, 159, 41-55. [CrossRef]

25. Shi, X.; Shi, Y. Conceptualizing entrepreneurial ecosystems: Definition, configurations and health. Acad. Manag. Proc. 2016, 1, 11074. [CrossRef]

26. Autio, E.; Thomas, L. Innovation Ecosystems: Implication for Innovation Management; Oxford University Press: Oxford, UK, 2014.

27. Cai, Y.; Ma, J.; Chen, Q. Higher education in innovation ecosystems. Sustainability 2020, 12, 4376. [CrossRef]

28. Chen, J.; Liu, X.; Hu, Y. Establishing a CoPs-based innovation ecosystem to enhance competence-The case of CGN in China. Int. J. Technol. Manag. 2016, 72, 144-170. [CrossRef]

29. Shaw, D.; Allen, T. Studying innovation ecosystems using ecology theory. Technol. Forecast. Soc. Chang. 2018, 136, 88-102. [CrossRef]

30. Adner, R. Match your innovation strategy to your innovation ecosystem. Harv. Bus. Rev. 2006, 84, 98-107.

31. Zahra, S.A.; Nambisan, S. Entrepreneurship and strategic thinking in business ecosystems. Bus. Horiz. 2012, 55, 219-229. [CrossRef]

32. Rohrbeck, R.; Hölzle, K.; Gemünden, H.G. Opening up for competitive advantage-How Deutsche Telekom creates an open innovation ecosystem. $R$ D Manag. 2009, 39, 420-430. [CrossRef] 
33. Teece, D.J. Profiting from technological innovation: Implications for integration, collaboration, licensing and public policy. Res. Policy. 1986, 15, 285-305. [CrossRef]

34. Santos, F.M.; Eisenhardt, K.M. Organizational boundaries and theories of organization. Organ. Sci. 2005, 16, 491-508. [CrossRef]

35. Nelson, R.; Winter, S.G. An Evolutionary Theory of Economic Change; Belknap Press/Harvard University Press: Cambridge, MA, USA, 1982.

36. Tsujimoto, M.; Kajikawa, Y.; Tomita, J.; Matsumoto, Y. A review of the ecosystem concept-Towards coherent ecosystem design. Technol. Forecast. Soc. Chang. 2018, 136, 49-58. [CrossRef]

37. Zhang, J.; Liang, X. Business ecosystem strategies of mobile network operators in the 3G era: The case of China mobile. Telecomm. Policy 2011, 35, 156-171. [CrossRef]

38. Huang, J.; Wang, H.; Wu, J.; Yang, Z.; Hu, X.; Bao, M. Exploring the key driving forces of the sustainable intergenerational evolution of the industrial alliance innovation ecosystem: Evidence from a case study of China's TDIA. Sustainability 2020, 12, 1320. [CrossRef]

39. Ding, L.; Wu, J. Innovation ecosystem of CNG vehicles: A case study of its cultivation and characteristics in Sichuan, China. Sustainability 2018, 10, 39. [CrossRef]

40. Pellikka, J.; Ali-Vehmas, T. Managing innovation ecosystems to create and capture value in ICT industries. Technol. Innov. Manage. Rev. 2016, 6, 17-24. [CrossRef]

41. Dattée, B.; Alexy, O.; Autio, E. Maneuvering in poor visibility: How firms play the ecosystem game when uncertainty is high. Acad. Manag. J. 2018, 61, 466-498. [CrossRef]

42. Talke, K.; Salomo, S.; Rost, K. How top management team diversity affects innovativeness and performance via the strategic choice to focus on innovation fields. Res. Policy 2010, 39, 907-918. [CrossRef]

43. Powell, T.C.; Lovallo, D.; Caringal, C. Causal ambiguity, management perception, and firm performance. Acad. Manag. Rev. 2006, 31, 175-196. [CrossRef]

44. Gazzaniga, M.; Heatherton, T.; Halpern, D. Psychological Science; Norton: New York, USA, 2010.

45. Teece, D.; Peteraf, M.; Leih, S. Dynamic capabilities and organizational agility: Risk, uncertainty and strategy in the innovation economy. Calif. Manage. Rev. 2016, 58, 13-35. [CrossRef]

46. Felin, T.; Foss, N.J.; Ployhart, R.E. The microfoundations movement in strategy and organization theory. Acad. Manag. Ann. 2015, 9, 575-632. [CrossRef]

47. Helfat, C.E.; Martin, J.A. Dynamic managerial capabilities. J. Manage. 2014, 41, 1281-1312. [CrossRef]

48. Maitland, E.; Sammartino, A. Managerial cognition and internationalization. J. Int. Bus. Stud. 2015, 46, 733-760. [CrossRef]

49. Agarwal, R.; Helfat, C.E. Strategic renewal of organizations. Organ. Sci. 2009, 20, 281-293. [CrossRef]

50. Harreld, J.B.; O’Reilly, C.A.; Tushman, M.L. Dynamic capabilities at IBM: Driving strategy into action. Calif. Manag. Rev. 2007, 49, 21-43. [CrossRef]

51. Ericsson, K.A.; Lehmann, A.C. Expert and exceptional performance: Evidence of maximal adaptation to task constraints. Annu. Rev. Psychol. 1996, 47, 273-305. [CrossRef]

52. Eggers, J.P.; Kaplan, S. Cognition and renewal: Comparing CEO and organizational effects on incumbent adaptation to technical change. Organ. Sci. 2009, 20, 461-477. [CrossRef]

53. Tyler, B.B.; Gnyawali, D.R. Mapping managers' market orientations regarding new product success. J. Prod. Innov. Manag. 2002, 19, 259-276. [CrossRef]

54. Danneels, E. Trying to become a different type of company: Dynamic capability at Smith Corona. Strateg. Manag. J. 2011, 32, 1-31. [CrossRef]

55. Yin, R.K. Case Study Research: Design and Methods; Sage Publications: London, UK, 2013.

56. Myers, M.D. Qualitative Research in Business \& Management; Sage: Los Angeles, CA, USA, 2009.

57. Klein, H.K.; Myers, M.D. A set of principles for conducting and evaluating interpretive field studies in information systems. MIS Q. 1999, 23, 67-93. [CrossRef]

58. Walsham, G. Doing interpretive research. Eur. J. Inf. Syst. 2006, 15, 320-330. [CrossRef]

59. Eisenhardt, K.M.; Graebner, M.E. Theory building from cases: Opportunities and challenges. Acad. Manag. J. 2007, 50, 25-32. [CrossRef]

60. Glaser, B.G.; Strauss, A.L. The Discovery of Grounded Theory: Strategies for Qualitative Research; Transaction Publishers: Piscataway, NJ, USA, 2009.

61. Pan, S.L.; Tan, B. Demystifying case research: A structured-pragmatic-situational (SPS) approach to conducting case studies. Inf. Organ. 2011, 21, 161-176. [CrossRef] 
62. Yin, R.K. Case Study Research; Sage Publications: London, UK, 2008.

63. Strauss, A.; Corbin, J. Basics of Qualitative Research Techniques; Sage Publications: Thousand Oaks, CA, USA, 1998.

64. Eisenhardt, K.M. Building theories from case study research. Acad. Manag. J. 1989, 14, 532-550.

65. Amitrano, C.C.; Tregua, M.; Russo Spena, T.; Bifulco, F. On technology in innovation systems and innovation-ecosystem perspectives: A cross-linking analysis. Sustainability 2018, 10, 3744. [CrossRef]

66. Liao, J.; Chen, X. The competition of ecosphere. 21st Century Bus. Rev. 2012, 12, 36.

67. Nerkar, A.; Roberts, P.W. Technological and product-market experience and the success of new product introductions in the pharmaceutical industry. Strateg. Manag. J. 2004, 25, 779-799. [CrossRef]

68. Yun, J.J.; Liu, Z. Micro and macro-dynamics of open innovation with a quadruple-helix model. Sustainability 2019, 11, 3301. [CrossRef]

69. Tasheva, S.; Nielsen, B.B. The role of global dynamic managerial capability in the pursuit of international strategy and superior performance. J. Int. Bus. Stud. 2020. [CrossRef]

70. Vecchiato, R. Disruptive innovation, managerial cognition, and technology competition outcomes. Technol. Forecast. Soc. Chang. 2017, 116, 116-128. [CrossRef]

71. Yakovleva, A.Y.; Volkova, I.O. Towards an innovation ecosystem: The case for stimulating collaboration in the Russian energy sector. In IOP Conference Series Earth and Environmental Science; IOP Publishing: Bristol, UK, 2018.

72. Srivastava, S.; Sahaym, A.; Allison, T.H. Alert and Awake: Role of alertness and attention on rate of new product introductions. J. Bus. Ventur. 2020. [CrossRef]

73. Anning-Dorson, T.; Odoom, R.K.; Acheampong, G.; Tweneboah-Koduah, E. Innovation and organizational development: The role of organizational leadership. Afr. J. Econ. Manag. Stud. 2017, 8, 338-351. [CrossRef]

74. Nittymies, A.; Pajunen, K. Cognitive foundations of firm internationalization: A systematic review and agenda for future research. Int. Bus. Rev. 2020. [CrossRef]

75. Bao, G.; Liao, Z.; Hine, D. Managerial cognition, emergency preparedness and firm's emergency response performance. J. Risk Res. 2019, 22, 1490-1502. [CrossRef]

76. Leia, V.C. Managerial cognition, strategy and performance of foreign SMEs in Romania. Int. Bus. Res. 2017, $10,48-67$.

77. Stanovich, K.E. What Intelligence Tests Miss: The Psychology of Rational Thought; Yale University Press: New Haven, CT, USA, 2009.

78. Ding, L.; Ye, M.; Wu, J. Platform strategies for innovation ecosystem: Double-case study of Chinese automobile manufactures. J. Clean. Prod. 2019, 209, 1564-1577. [CrossRef]

79. Samba, C.; Van Knippenberg, D.; Miller, C.C. The impact of strategic dissent on organizational outcomes: A meta-analytic integration. Strateg. Manag. J. 2018, 39, 379-402. [CrossRef]

80. Su, Y.; Zheng, Z.; Chen, J. A multi-platform collaboration innovation ecosystem: The case of China. Manag. Decis. 2018, 56, 125-142. [CrossRef]

81. Kwak, K.; Kim, W.; Park, K. Complementary multiplatforms in the growing innovation ecosystem: Evidence from 3D printing technology. Technol. Forecast. Soc. Chang. 2018, 136, 192-207. [CrossRef]

82. Gao, Y.; Liu, X.; Ma, X. How do firms meet the challenge of technological change by redesigning innovation ecosystem: A case study of IBM. Int. J. Technol. Manag. 2019, 80, 241-265. [CrossRef]

83. Camison-Haba, S.; Clemente-Almendros, J.; Gonzalez-Cruz, T. How technology-based firms become also highly innovative firms? The role of knowledge, technological and managerial capabilities, and entrepreneurs' background. J. Innov. Knowl. 2019, 4, 162-170.

84. Sarfraz, M.; Ozturk, I.; Shah, S.G.M.; Maqbool, A. Contemplating the impact of the moderators agency cost and number of supervisors on corporate sustainability under the Aegis of a cognitive CEO. Front. Psychol. 2020, 11. [CrossRef] [PubMed]

85. Kumbure, M.M.; Tarkiainen, A.; Luukka, P.; Stoklasa, J.; Jantunnen, A. Relation between managerial cognition and industrial performance: An assessment with strategic cognitive maps using fuzzy-set qualitative comparative analysis. J. Bus. Res. 2020, 114, 160-172. [CrossRef]

86. Acciarini, C.; Brunetta, F.; Boccardelli, P. Cognitive biases and decision-making strategies in times of change: A systematic literature review. Manag. Decis. 2020. [CrossRef]

87. Lyon, D.W.; Ferrier, W.J. Enhancing performance with product-market innovation: The influence of the top management team. J. Manag. Issues. 2002, 14, 452-469.

88. Gibson, C.B.; Birkinshaw, J. The antecedents, consequences, and mediating role of organizational ambidexterity. Acad. Manag. J. 2004, 47, 209-226. 
89. Roberts, N.; Qahri-Saremi, H.; Vijayasarathy, L.R. Understanding IT value at the managerial level: Managerial ambidexterity, seizing opportunities, and the moderating role of information systems use. Data Base Adv. Inf. Syst. 2020, 51, 1-23. Available online: http://dl.acm.org/citation.cfm?id=J219 (accessed on 30 August 2020).

90. Yang, D.; Wang, A.; Zhou, K.; Jiang, W. Environmental strategy, institutional force, and innovation capability: A managerial cognition perspective. J. Bus. Ethics 2019, 159, 1147-1161. [CrossRef]

91. Wójcik, P.; Ciszewska-Mlinarič, M. The impact of cognitive and behavioral factors on the export performance: A dynamic capabilities perspective. Eur. Econ. Rev. 2020. [CrossRef]

92. Engler, D.; Yang, H.; Kim, J. Managerial cognitive capabilities, mental representations of routines and market entry by analogy. Acad. Manag. Proc. 2017. [CrossRef]

93. Bergman, J.P.; Luukka, P.; Jantunen, A.; Tarkiainen, A. Cognitive diversity, managerial characteristics and performance differences across the cleantech firms. Int. J. Knowl. Based Organ. 2020. [CrossRef]

(C) 2020 by the authors. Licensee MDPI, Basel, Switzerland. This article is an open access article distributed under the terms and conditions of the Creative Commons Attribution (CC BY) license (http://creativecommons.org/licenses/by/4.0/). 